\title{
Master of Science with Emerging Specializations and Honours/Major: A Case of IT \& Computing Fields in Indian Private Universities
}

\author{
P. K. Paul ${ }^{1}$, P. S. Aithal ${ }^{2}$ and K. S. Shivraj ${ }^{3}$ \\ ${ }^{1}$ Raiganj University (RGU), West Bengal, India \\ ${ }^{2}$ Vice-Chancellor, Srinivas University, Karnataka, India \\ ${ }^{3}$ Head-Learning Resource Centre, KL University, Andhra Pradesh India \\ E-Mail: pkpaul.infotech@gmail.com
}

\begin{abstract}
Technology is changing day by day with rapid development in many areas of Science and Technology. Higher Educational Institutes (HEIs) worldwide developed and creating many new emerging concepts, fields and study. Computing and Information Technology related fields in recent past developed in rapid speed. There are many organizations, institutions, establishments, and sectors purely and partially depend on computing and allied tools and technologies; and as a result, the field of computing and IT has been changed radically in the different context. The growing requirement of information in diverse areas lead several branches for its nurturing and among these Computing and Information Technology are most important and valuable. Initially, the branch in this field was called as Computer Science but gradually the importance and uses of information have resulted in several other allied branches concentrated on information. Apart from core areas, several new areas of Information Technologies have been developed in recent past; among these few important are Networking Technologies, Web Technologies, Database Technologies, Multimedia Technologies etc. In India, Higher Educational Institutes (HEIs) developed rapidly after 1980's and most significantly in last decade. The private player plays a lead role in this respect in terms of producing skilled manpower. Private universities are the latest example of higher educational institutions in this regard. The branches of Computing and Information Technology have been changed a lot with the hands of private universities. The educational models and programs in IT and Computing fields have been changed rapidly in last few years by the initiatives undertaken by the private universities. This work is a primary study designed to show the educational systems in India emphasizing emerging programs in IT and Computing in Private Universities in India. The Concept of Major and Concentration of a specific subject previously was important only in Bachelor's degrees but in recent past Masters degrees are also available with such specializations and concentration with the efforts of private universities in India. The paper is fully dedicated to show such affairs briefly. Keywords: Private Universities, India, Development, Skilled Manpower, M.Sc., Honors, Specializations, Research Degrees
\end{abstract}

\section{INTRODUCTION}

Information Technology is a technology concentrated on information affairs leading to the collection, selection, organization, processing, management, and dissemination [1], [5], [8]. It is thus, deals with several technologies responsible for the information related affairs. Though the traditional branch i.e. Computer Science is primarily responsible for studying internal areas of computer systems and computing systems as well. Worldwide Information Technology related branches are available also in other flavors viz. Information Systems, Information Science, Information Engineering, Computing, Computer Engineering etc [2], [3], [7]. In India, in Computing track, only Computer Science and Computer Application becomes popular and most available in Indian Universities. In the areas of Computing and IT, few emerged areas are Big Data Technologies, Human Computer Interaction, Cloud Computing, Information Security etc. It is important to note that worldwide IT Components viz. Database Technology, Networking Technology, Web Technology, Multimedia Technology are also available as a Master's program like M.Sc. Networking Technology. Though India holds a large number of Higher Educational Institutes in the world but diversity in the level of programs and subjects is very much limited [4], [6], [11]. But in recent past Indian private universities are doing well in this regard in terms of new age programs and specializations. Even introducing Major and Honors in IT and Computing is also a wonderful initiative by the private universities in India.

\section{OBJECTIVES}

The paper is theoretical in nature but it has the structure of interdisciplinary sciences as concentrated on educational affairs including technological sciences. The core aim and agenda of the paper is mentioned as follows:

1. To learn about the basics of Computing and Information Technology related subjects and domains.

2. To dig out the educational programs available in Computing and Information Technology related subjects, internationally and in India.

3. To learn about the emerging areas and fields in the field of Computing and Information Technology related subjects.

4. To learn about the Higher Educational Systems in India with reference to the private universities in India.

5. To learn about the rising trend of specializations of Computing and Information Technology in M.Sc. programs. 
6. To learn about the rising trend of Honors/ Major and Concentration of Computing and Information Technology in M.Sc. programs.

\section{METHODS ADOPTED}

The present work is dedicated to learn about the higher education systems in India in brief with reference to learn about the Computing and Information Technology programs available in India. The work concentrated on to dig out the latest of Computing and IT fields as a field of study and specializations. Hence mixed mode of methods have been adopted for the present work, and initially, review of the literature has been undertaken to learn about Indian HEIs and also to learn about the computing and IT field as basics. Moreover, apart from the review of literature web review plays a great role and in this regard, various websites have been analyzed and reported in this work. The core URL considered in this regard is https://www.ugc.ac.in/privatuniversity.aspx. Other related websites of the AICTE, UGC also been considered and play a great role in this regard.

\section{A. Universities in India with Private Universities}

India is one of the largest democracies in the world. Indian education sectors are classified into three major viz. School Education, College Education, and University Education. Though apart from these Research Centres, Autonomous Bodies etc are also fall under this category. India holds $800+$ Universities and within this major categories which include
1. Central University
2. State University
3. Private University
4. Deemed to be University

As far as Private Universities are concerned it has now reached to 279 (as on October, 2017) and the details of statewide statistics are depicted in Table I.

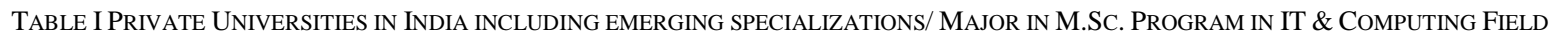

\begin{tabular}{|c|c|c|c|c|}
\hline S. No. & States & No. of Universities & $\begin{array}{c}\text { No. of Universities } \\
\text { with Specialized } \\
\text { Programs } \\
\end{array}$ & $\begin{array}{l}\text { No. of with Focused } \\
\text { M.Sc. in Computing/IT } \\
\text { related area }\end{array}$ \\
\hline 1 & Arunachal Pradesh & 7 & 1 & 5 \\
\hline 2 & Assam & 5 & Nil & Nil \\
\hline 3 & Bihar & 2 & Nil & Nil \\
\hline 4 & Chhattisgarh & 9 & 1 & 1 \\
\hline 5 & Gujarat & 30 & 6 & 15 \\
\hline 6 & Haryana & 20 & 1 & 1 \\
\hline 7 & Himachal Pradesh & 17 & Nil & Nil \\
\hline 8 & Jharkhand & 7 & Nil & Nil \\
\hline 9 & Karnataka & 14 & 1 & 4 \\
\hline 10 & Meghalaya & 8 & Nil & Nil \\
\hline 11 & Mizoram & 1 & Nil & Nil \\
\hline 12 & Madhya Pradesh & 24 & Nil & Nil \\
\hline 13 & Maharashtra & 9 & Nil & Nil \\
\hline 14 & Manipur & 1 & Nil & Nil \\
\hline 15 & Nagaland & 3 & Nil & Nil \\
\hline 16 & Odisha & 4 & Nil & Nil \\
\hline 17 & Punjab & 15 & 3 & 3 \\
\hline 18 & Rajasthan & 46 & 1 & 1 \\
\hline 19 & Sikkim & 5 & Nil & Nil \\
\hline 20 & Tripura & 1 & Nil & Nil \\
\hline 21 & Uttar Pradesh & 29 & 4 & 5 \\
\hline 22 & Uttrakhand & 13 & Nil & Nil \\
\hline 23 & West Bengal & 9 & 1 & 2 \\
\hline \multicolumn{2}{|r|}{ Grand Total } & 279 & 19 & 37 \\
\hline
\end{tabular}


The large numbers of universities are located in the State of Rajasthan (total 46) whereas the state Gujarat holds the second position in terms of private universities in India (with total 30 universities); Uttar Pradesh scored $3^{\text {rd }}$ position (with total 29 universities).

\section{B. IT and Computing Program in the World Vs. India}

Information and Computing related domains may be classified into two, first one is Computing related and second one is Information/IT oriented. The Computing related areas constituted with Computer Science, Computer Engineering, Computer Applications etc. whereas in Information/IT area major areas are Information Technologies, Information Systems, Information Management, Information Science [9], [12], [15].

Though in India, commonly available disciplines are Computer Science, Computer Science and Engineering (CSE); and from Information area Information Technology is only available track. It is an important fact that Information Technology is concentrated with Information and thus it is supported by the technologies viz. Database Technologies, Network Technologies, Web Technologies, Multimedia Technologies, Communication Technologies etc [9], [10], [13]. And internationally many universities have started even Bachelors and Masters in these sub-fields viz. BS/MS-Networking Technologies, BS/MS-Web Technologies. India is developing rapidly and as a result educational programs are also changing including areas of interest, degrees, methods of education \& teaching and so on. Private Universities are doing well in this regard for offering programs in the emerging areas or subfields of Information Technology [6], [13], [14].
C. M.Sc. Computing related Programs into New Heights: The Craze of Specializations

The private universities are taking an important step for the development of IT and Computing related education into new heights and in this regard [7],[16], they are following the international level of education systems, degrees and nomenclature, and thus many universities have started programs in this regard. Interestingly among the sub fields of Information Technologies, many universities have started programs in the field with nomenclatures such as:
1. M.Sc. Multimedia
2. M.Sc. Animation
3. M.Sc. Data Analytics
4. M.Sc. Network Technology \& Management etc.

Important to note that the emerging and super specialty areas within the sub-fields of Information Technologies have raised and few important are include- Cloud Computing, Information Security, Big Data Technologies, Usability Engineering, Human Computer Interactions, Information Security etc. And many international universities also have stared full-fledged degrees in these areas. The private universities in India are also taken an important initiative for starting such degrees in India as well. The study shows that among 279 universities in this segment 21 programs are in the emerging specializations mentioned above. Though, in some universities, few programs are available as emerging specializations and areas as a Major in M.Sc.-IT or M.Sc.-CS Program.

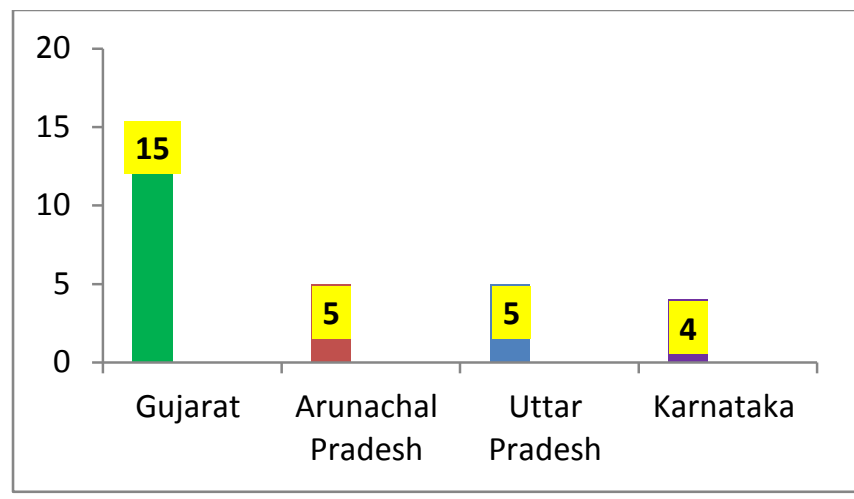

Fig. 1 State wise distribution of Private Universities with reference to emerging areas in M.Sc. in IT \& Related areas

The study analyzed and reported that total 37 programs are available in this segment with few are direct as M.Sc. program and few as a Major/ Honors in M.Sc. program. As a whole Rajasthan holds the first position with 15 programs while Andhra Pradesh and Uttar Pradesh jointly hold second position (Please refer Fig: 1 for more details in this regard).

Himalayan University, Arunachal Pradesh holds the first position in terms of the number of specialized programs (total five programs), whereas Brainware University, West Bengal stands second positions with MA/M.Sc.-Multimedia \& Web Development M.Sc.-Hardware \& Networking. Mody University of Science and Technology, Rajasthan offers only one program on Information Security with the nomenclature M.Sc.-Digital Forensic \& Information Security. 
TABle II Private Universities IN INDIA OFFERING SPECIALIZATIONS/ MAJOR IN M.SC. PROGRAM IN IT \& COMPUTING FieLD

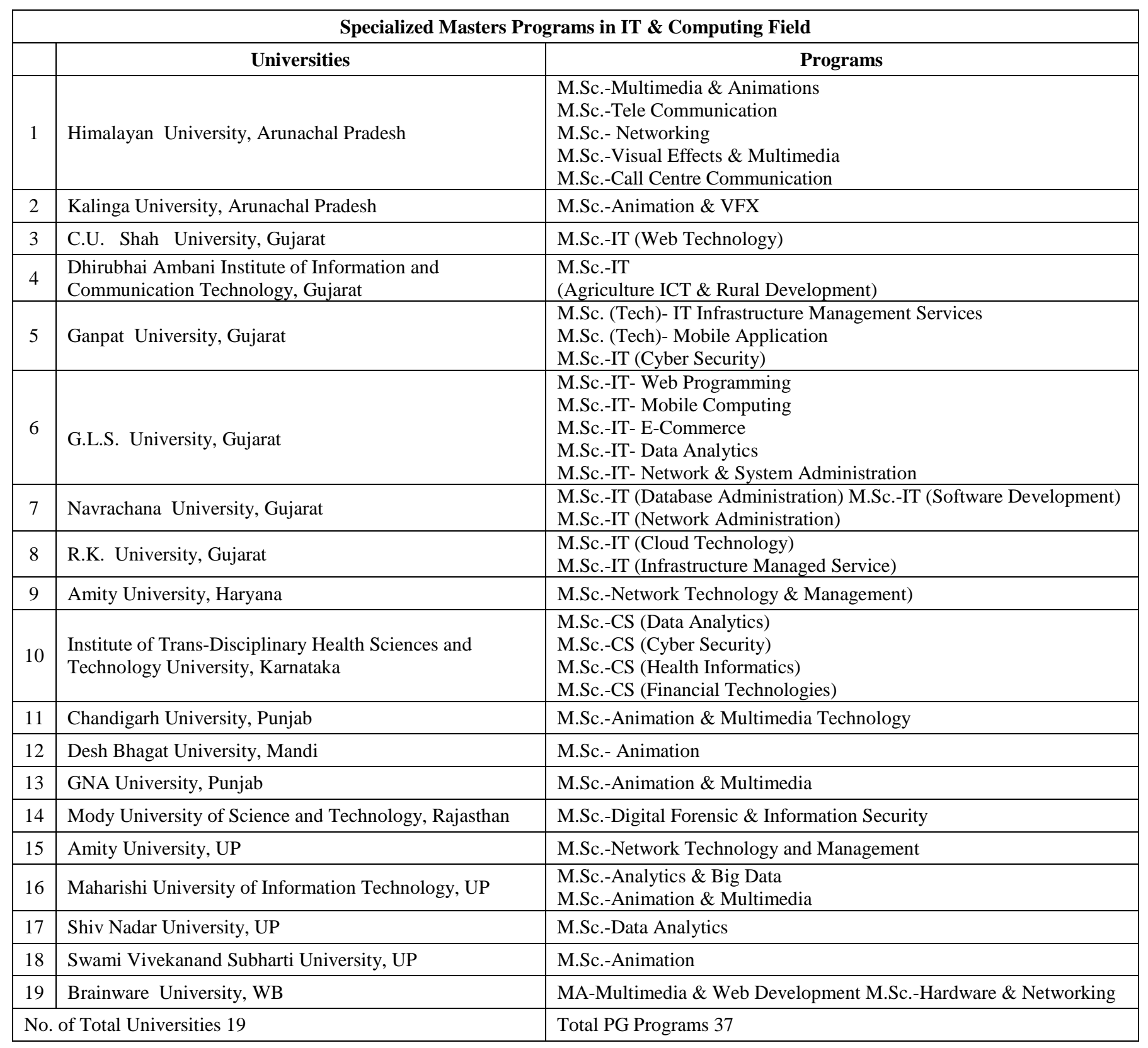

D. Major and Honors in M.Sc. Program: Indian Private University Context

Apart from the specialized program with M.Sc. degree in the field of Information Technology and Computing in recent past, another important initiative was undertaken by many private universities. Total 16 programs are available in this concentration/major segment. This kind of major is offered within the subject Information Technology/ Computer Science. This is an important initiative by the private universities, as one degree can serve the benefit of two.

For example, an M.Sc.-Networking can only eligible in the Networking Segment of job etc whereas an M.Sc.-IT
(Networking Technology) can serve both Networking related areas and traditional IT jobs. Moreover, in many cases, the degrees in a specialized field may not be considered for the job or higher studies as in most of the cases the broad branches are invited by the organizations and universities etc. Thus it is better to offer the specialized areas and sub fields of IT and Computing within the tag of broad field viz. M.Sc.-IT/CS (Major/Specialization). The Fig: 2 depict the distribution of Majors within M.Sc.-CS and M.Sc.-IT. 


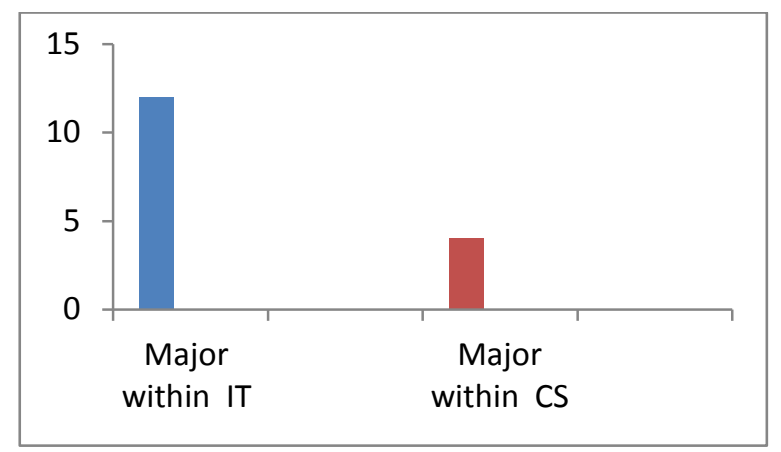

Fig. 2 Distribution of Major/ Honours M.Sc.-IT/CS: Case of Private Universities

As far as Major and Specializations within the IT and Computing related subjects are concerned most demanded in industries are include Web Technology, Database
Master of Science with Emerging Specializations and Honours/Major: A Case of IT \& Computing Fields in Indian Private Universities

Technology, Networking Technology whereas among the more emerging fields and programs few important are include

1. M.Sc.-IT (Cloud Technology)

2. M.Sc.-IT (Infrastructure Managed Service)

3. M.Sc.-IT (Data Analytics).

Apart from skill based areas some important programs are M.Sc.-IT (Agriculture ICT \& Rural Development), M.Sc.CS (Health Informatics), M.Sc.-CS (Financial Technologies), and M.Sc.-IT (E-Commerce). All these programs are sector specific Viz. Commerce, Healthcare, Finance, Agriculture. The details of the major programs have been depicted in Table III.

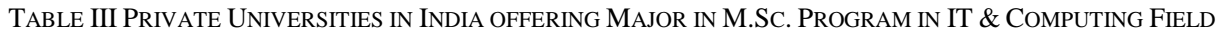

\begin{tabular}{|c|c|c|}
\hline \multicolumn{3}{|c|}{$\begin{array}{c}\text { Major \& Concentration in } \\
\text { Masters Programs in IT \& Computing }\end{array}$} \\
\hline & Universities & Programs \\
\hline 1 & C.U. Shah University, Gujarat & M.Sc.-IT (Web Technology) \\
\hline 2 & $\begin{array}{l}\text { Dhirubhai Ambani Institute of Information and } \\
\text { Communication Technology, Gujarat }\end{array}$ & $\begin{array}{l}\text { M.Sc.-IT } \\
\text { (Agriculture ICT \& Rural Development) }\end{array}$ \\
\hline 3 & G.L.S. University, Gujarat & $\begin{array}{l}\text { M.Sc.-IT (Web Programming) } \\
\text { M.Sc.-IT (Mobile Computing) } \\
\text { M.Sc.-IT (E-Commerce) } \\
\text { M.Sc.-IT (Data Analytics) } \\
\text { M.Sc.-IT (Network \& System Administration) }\end{array}$ \\
\hline 4 & Navrachana University, Gujarat & $\begin{array}{l}\text { M.Sc.-IT (Database Administration) } \\
\text { M.Sc.-IT (Software Development) } \\
\text { M.Sc.-IT (Network Administration) }\end{array}$ \\
\hline 5 & R.K. University, Gujarat & $\begin{array}{l}\text { M.Sc.-IT (Cloud Technology) } \\
\text { M.Sc.-IT (Infrastructure Managed Service) }\end{array}$ \\
\hline 6 & $\begin{array}{l}\text { Institute of Trans-Disciplinary Health Sciences } \\
\text { and Technology University, Karnataka }\end{array}$ & $\begin{array}{l}\text { M.Sc.-CS (Data Analytics) } \\
\text { M.Sc.-CS (Cyber Security) } \\
\text { M.Sc.-CS (Health Informatics) } \\
\text { M.Sc.-CS (Financial Technologies) }\end{array}$ \\
\hline \multicolumn{2}{|r|}{ No. of Total Universities 6} & Total PG Programs 16 \\
\hline
\end{tabular}

It is worthy to note that these 16 programs i.e. M.Sc.-IT/CS Major in emerging areas are basically governed by the 6 private universities. The specializations directly with M.Sc. though offer in large numbers but the craze of M.Sc.-IT/CS with major is important to note (refer Fig: 3 for clarification).

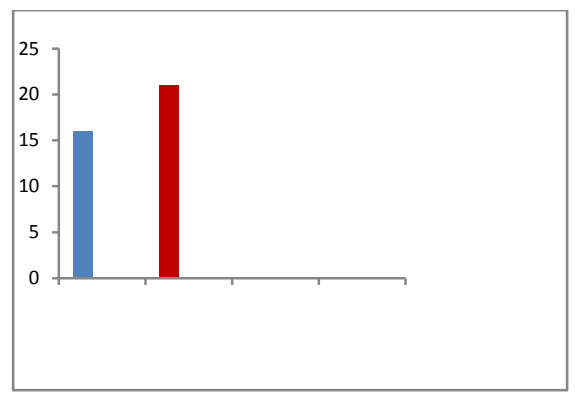

Fig. 3 The distribution of Specializations and Major in M.Sc. Degree

\section{FINDINGS}

1. The Computing and Information Technology branch is one of the largest within the field of Science and Technology and thus many nomenclatures are available viz. Computer Science, Computer Engineering, Computer Applications etc. Whereas in Information related fields major areas are Information Technologies, Information Systems, Information Management, and Information Science.

2. In India common Masters programs in Computing and IT related are M.Sc.-Information Technology/ Computer Science, MCA; though in Engineering segment the IT and CS are also available with ME/MTech award.

3. India is the largest educational system with over 40000+ HEIs combines with College, Universities and Research Centres, Institutions etc. Among these about 
$800+$ are universities and 279 are private universities (as on October, 2017).

4. It is important to note that IT is constituted with various components viz. Database Technology, Networking Technology, Web Technology, Multimedia Technology and in 6 Private Universities 16 programs are available with M.Sc.-IT/CS.

5. Though apart from concentration within M.Sc.-IT/CS these components and few emerging areas of IT and Computing viz. Big Data Technologies, Cloud Computing, Information Security etc. are also offered by the private universities directly with M.Sc. degree.

6. In respect of Job and wide acceptance the broader branches are still important in India and thus universities are switching to Major/Honors in this segment.

\section{SUGGESTIONS}

1. Private Universities in India offering different nomenclature in IT and Computing though in respect of international picture still is limited and thus few broad domain/ subjects may be offered Information Systems, Information Management, Information Science, and Information Science and Technology.

2. Within the emerging areas, many left subjects may be offered with M.Sc. degree either directly as a specialization or Major within M.Sc.-CS/IT.

3. Universities may collaborate with other organizations, industries for the solid development of training and placement.

4. Like Private Universities; other universities may also offer such kind of emerging specializations/ skill based degrees.

5. Already many universities have started programs on Skill based areas and technologies but it is worthy to start other domain centric programs viz. Bio Informatics, Geo Informatics, Chem Informatics, Eco Informatics etc as an M.Sc. -IT/IS Specializations.

\section{CONCLUSION}

Education System is changing rapidly. In India initially only government universities are responsible for the educational delivery, training and research affairs. But gradually private universities have been developed and many other affairs thus within university segment. Among these affairs industry integrated programs, placement \& training, skill based programs etc found importance. Private Universities are doing well in respect of the development of manpower and industrial promotion; directly and indirectly in diverse areas viz. Big Data Technologies, Human Computer Interaction, Cloud Computing, Information Security. It is worthy to note that the specializations may be offered within the M.Sc. degree in other broad areas and in this respect Information Science or Information Systems may be selected as these are applied in nature and works for the organizations, industries, and society. The M.Sc.-CS may be offered in respect of designing of the tools and technologies. For example, M.Sc.-IT/IS (Big Data) may be a program on how to utilize Big Data etc for the organizations and industries whereas M.Sc.-CS (Big Data) may be offered for design and development context of Big Data rather applications. Hence universities need to adopt the nomenclature based on requirement. In a country like India a Major/Honors would be best instead of Specializations with direct M.Sc. degree.

\section{REFERENCES}

[1] Tijerina, K. H., \& Biemer, P. P. "The Dance of Indian Higher Education: One Step forward, Two Steps back”, Educational Record, vol. 68, No. 4, pp. 86-91, 1988.

[2] Tilak, J. B., \& Varghese, N. V., "Financing higher education in India”, Higher Education, vol. 21, No.1, pp. 83-101, 1991.

[3] Tate, D. S., \& Schwartz, C. L., "Increasing the retention of American Indian students in professional programs in higher education”, Journal of American Indian Education, pp. 21-31, 1993.

[4] Supe, A., \& Burdick, W. P., "Challenges and issues in medical education in India”, Academic Medicine, vol. 81, No. 12, pp. 10761080, 2006.

[5] Bhattacharya, I., \& Sharma, K., "India in the knowledge economy-an electronic paradigm”, International Journal of Educational Management, vol. 21, No. 6, pp. 543-568, 2007.

[6] Agarwal, P., "Higher education in India: Growth, concerns and change agenda”, Higher Education Quarterly, vol. 61, No.2, pp. 197207, 2007.

[7] Umashankar, V., \& Dutta, K., "Balanced scorecards in managing higher education institutions: an Indian perspective", International Journal of Educational Management, vol. 21, No. 1, pp. 54-67, 2007.

[8] Tilak, J. B., "Transition from higher education as a public good to higher education as a private good: The saga of Indian experience”, Journal of Asian Public Policy,vol. 1, No. 2, pp. 220234, 2008.

[9] Desai, S., \& Kulkarni, V., “Changing educational inequalities in India in the context of affirmative action”, Demography, vol. 45, No. 2, pp. 245-270, 2008.

[10] Gereffi, G., Wadhwa, V., Rissing, B., \& Ong, R., “Getting the numbers right: International engineering education in the United States, China, and India”, Journal of Engineering Education, vol. 97, No. 1, pp. 13-25, 2008.

[11] Tayade, M. C., \& Kulkarni, N. B., "The Interface of technology and medical education in india: current trends and scope", Indian Journal of Basic \& Applied Medical Research, vol. 1, No. 1, pp. 8-12, 2011.

[12] Gupta, D., \& Gupta, N., "Higher education in India: structure, statistics and challenges”, Journal of education and Practice, vol. 3, No. 2, 2012.

[13] Paul, P. K., \& Ghose, M. K., "A Novel Educational Proposal and Strategies Toward Promoting Cloud Computing, Big Data, and Human-Computer Interaction in Engineering Colleges and Universities", In Advances in Smart Grid and Renewable Energy, Vol. 435 , pp. 93-102. Springer, Singapore, 2018.

[14] Paul, P.K., Bhuimali, A. \& Aithal, P. S., "Indian Higher Education: With Slant to Information Technology - a Fundamental Overview", International Journal on Recent Researches In Science, Engineering \& Technology, vol. 5, No. 11, pp. 31-50.

[15] Paul, P. K., Aithal, P. S. \& Bhuimali, A., Computing \& Allied Engineering Domain in India with Reference to Private Universities: A Case Study of Bachelors Programs, International Journal on Recent Researches In Science, Engineering \& Technology,vol. 5, No. 11, pp. 51-63.

[16] Paul, P.K., Aithal, P. S. \& Bhuimali, A., "MCA (Information Science and Management): The next Generation Interdisciplinary Specialization for Better Social Informatics and Digital Humanities Practice", International Journal of Scientific Research in Mathematical and Statistical Sciences, vol. 4, No. 5, pp. 27-32. 